\title{
MODEL PENDIDIKAN KARAKTER ANAK USIA DINI DI PONDOK PESANTREN AL HIKAM KOTA MALANG
}

\author{
Siti Muntomimah \\ Dosen PG PAUD FIP Universitas Kanjuruhan Malang Jl. S.Supriadi No. 48 Malang \\ mutomimahm1@gmail.com
}

\begin{abstract}
Abstrak: Penelitian ini dilakukan untuk mengetahui model pendidikan dan pembelajaran karakter anak usia dini dengan setting pembelajaran di institusi pondok pesantren. Penelitian ini menggunakan metode studi kasus kualitatif, \& menggunakan teknik analisis model Miles \& Hubberman. Penelitian ini dilakukan di Raudlotul Athfal (RA) Al Hikam di Pondok Pesantren (Ponpes) Al Hikam, Kota Malang. Berdasarkan penelitian yang dilakukan, model pembelajaran karakter anak usia dini yaitu dengan cara (1) pembiasaan oleh guru \& (2) imitasi dari santri di lingkungan sekolah. Sedangkan faktor-faktor yang mempengaruhi model pendidikan dan pembelajaran karakter anak usia dini di lingkungan ponpes adalah: (1) karakter pondok pesantren, (2) integritas dan komitmen orangtua murid, (3) keteladanan guru-guru RA.
\end{abstract}

Kata Kunci: karakter, pesantren, kiai

Abstract: This study was conducted to determine the education models of early childhood learning character in boarding school (pesantren) setting. This study uses a qualitative case study, and using Miles \& Hubberman model for techniques analysis. This research was conducted in Raudlotul (RA) Al Hikam boarding school (pesantren) Al Hikam, Malang. Based on the research, learning model for early childhood character is by (1) habituation by teachers and (2) imitation of students (santri) in the school environment. While the factors that influence the character of the education model in the early childhood environment (ponpes) are: (1) ponpes the characteristics, (2) integrity and commitment of parents, (3) exemplary teachers $R A$.

Kata kunci: character, boarding school (pesantren), sitter (kiai), learning \& education models

\section{PENDAHULUAN}

Masa usia dini, umur $0-6$ tahun adalah masa usia emas, masa terbaik pembentukan kepribadian dan karakter manusia, yang akan menjadikannya manusia terbaik jika mampu disiapkan dengan sebaik-baiknya. Prof. Dr. Lydia Freyani Hawadi, Psi menyatakan usia dini merupakan periode perkembangan yang sangat penting dalam kehidupan manusia. Pada masa ini, seluruh instrumen besar manusia terbentuk, bukan kecerdasan saja tetapi seluruh kecakapan psikis. Para ahli menamakan periode ini sebagai usia emas perkembangan. ${ }^{1}$ Pada masa ini pula kerentanan dan urgensi pembentukan karakter manusia mencapai titik yang paling penting,

1 Lydia Freyani Hawadi, Pedoman Pendidikan Karakter Pada Pendidikan Anak Usia Dini, Direktorat Pembinaan Pendidikan Anak Usia Dini, Kementerian Pendidikan Nasiona, 2012 sebagaimana disimpulkan oleh Laksana bahwa pembangunan pendidikan karakter bagi anak usia SD sangat penting sekali karena dapat memberikan manfaat yang sangat luar biasa diantaranya yaitu: menumbuhkan rasa cinta kepada Tuhannya, orang tuanya dan kepada orang-orang disekitarnya; mendidik rasa tanggung jawab dan disiplin. ${ }^{2}$

Pendidikan dan pembelajaran karakter bisa diperoleh dimana saja, secara formal, non formal dan informal, oleh subyek-subyek yang mempunyai pengaruh penting pada pembentukan kepribadian, norma, nilai, agama, moral, interaksi, dan sosial-emosional anak. Pendidikan dan pembelajaran karakter juga bisa diperoleh di lingkungan keluarga, sekolah dan

2 Sigit Dwi Laksana, Urgensi Pendidikan Karakter, MUADDIB, Vol.05 No.01 Januari-Juni 2015, jurnal.umpo.ac.id, diakses: 01/08/2016 
masyarakat. Dalam keluarga, orangtua dan famili serta subyek-subyek yang sangat dekat dengan anak mempunyai pengaruh penting pembentukan karakter anak. Di masyarakat, subyek yang berpengaruh hampir tidak terbatas jumlahnya, seperti tokoh masyarakat \& tokoh agama. Demikian halnya dengan lingkungan sekolah, yaitu guru sebagai subyek vital perkembangan karakter anak usia dini. Prof. Dr. H. Sofyan Sauri, M.Pd menyatakan bahwa guru memiliki peran strategis untuk menjadi bagian penting dalam upaya membangun karakter bangsa. Hal tersebut dapat diwujudkan melalui peran serta guru secara optimal dalam proses penyiapan peserta didik yang memiliki karakter sebagaimana disebutkan dalam UU No 20 Tahun 2003 Bab II Pasal 3 tentang fungsi dan tujuan pendidikan nasional. Karakter dan mentalitas sumber daya manusia suatu bangsa akan menjadi pondasi dari tata nilai bangsa tersebut. Dalam tataran operasional, upayaupaya nyata dalam membentuk dan memelihara karakter dan mentalitas tersebut bisa dilakukan oleh sosok guru professional. ${ }^{3}$

Guru dan sekolah adalah 2 (hal) yang tidak bisa dilepaskan pengaruhnya satu sama lain. Sekolah, sebagai institusi pendidikan dengan segala atributnya mempunyai masing-masing ciri khas dan keunikan tersendiri dalam proses pembelajarannya, seperti sekolah umum dengan ciri khas nasionalis dan sekolah agama dengan basis keagamaan dan fokus yang lebih banyak pada bidang moral dan spiritual. Institusi pesantren termasuk dalam kategori sekolah dengan basis agama. Prof. Dr. H. Sofyan Sauri, M.Pd menyatakan bahwa dalam prakteknya, di samping menyelenggarakan kegiatan pengajaran, pesantren juga sangat memperhatikan pembinaan pribadi melalui penanaman tata nilai dan kebiasaan di lingkungan pesantren. Seiring

3 Sofyan Sauri, Membangun Karakter Bangsa melalui Pembinaan Profesionalisme Guru Berbasis Pendidikan Nilai, Jurnal Pendidikan Karakter, 2010 - file.upi.edu; diakses: 01/08/2016 dengan perkembangan ilmu pengetahuan dan teknologi serta pergeseran paradigma pembangunan pendidikan, pesantren kini digiring untuk dilengkapi dengan pendidikan formal, sehingga pesantren di samping menyelenggarakan pendidikan non formal juga menyelenggarakan pendidikan formal. ${ }^{4}$

Dengan model edukasi untuk anak usia dini di lingkungan pesantren yang bersifat komprehensif dan mengikat dengan setting lokasi yang unik, maka output hasil pembelajaran dan pendidikan di lingkungan pesantren mempunyai ciri khas tersendiri dibandingkan dengan model pendidikan dan pembelajaran di sekolah umum. Keunikankeunikan dari output hasil pembelajaran dan pendidikan di lingkungan pesantren, misalnya pada kepribadian, sosial emosional, spritualitas, dan tidak terkecuali dengan karakter peserta didik usia dini.

\section{Pendidikan Karakter}

Saat usia dini, lebih mudah membentuk karakter anak. Sebab, ia lebih cepat menyerap perilaku dari lingkungan sekitarnya. Pada usia ini, perkembangan mental berlangsung sangat cepat. Oleh karena itu, lingkungan yang baik akan membentuk karakter yang positif. Pengalaman anak pada tahun pertama kehidupannya sangat menentukan apakah ia akan mampu menghadapi tantangan dalam kehidupannya dan apakah ia akan menunjukkan semangat tinggi untuk belajar dan berhasil dalam pekerjaannya. ${ }^{5}$

Gutama menjelaskan bahwa karakter terbentuk sebagai hasil pemahaman dari hubungan dengan diri sendiri, dengan lingkungan (hubungan sosial dan alam sekitar), dan hubungan

4 Sofyan Sauri, Peran Pesantren Dalam Pendidikan Karakter, MAN Baturaja: siap-sekolah.com - page:3, diakses: 01/08/2016

5

Gutama, Pendidikan Karakter Pada Anak Usia Dini, bahan kuliah Perkembangan Anak Usia Dini, Program Studi Pendidikan Anak Usia Dini Pascasarjana Universitas Negeri Jakarta, 2009 
dengan Tuhan YME (triangle relationship), sebab itu: (1) tumbuhkan pemahaman positif pada diri anak sejak usia dini, (2) biasakan anak bersosialisasi dan berinteraksi dengan lingkungan sekitar. ${ }^{6}$

\section{Pesantren}

Abdurrahman Wahid memberikan pemahaman tentang pesantren, adalah sebuah komplek dengan lokasi yang umumnya terpisah dari kehidupan di sekitarnya di mana dalam komplek tersebut berdiri beberapa bangunan rumah, kediaman pengasuh, sebuah surau atau masjid tempat pengajaran diberikan, dan asrama tempat tinggal para siswa pesantren (santri). Pesantren yang dianggap sebagai lembaga pendidikan tradisional memiliki beberapa aspek kehidupan, diantaranya pemberian pengajaran dengan struktur, metode dan literatur tradisional, serta pemeliharaan tata nilai tertentu, atau bisa dikatakan sebagai "subkultur pesantren".

Sistem yang ditampilkan pondok pesantren menurut Hasbullah mempunyai keunikan dibandingkan dengan sistem yang diterapkan dalam pendidikan pada umumnya, yaitu: (1) memakai sistem tradisional yang mempunyai kebebasan penuh di bandingkan dengan sekolah modern, sehingga terjadi hubungan dua arah antara santri dan kiai, (2) kehidupan di pesantren menampakkan semangat demokrasi karena mereka praktis bekerja sama mengatasi problem nonkurikuler mereka, (3) para santri tidak mengidap penyakit simbolis, yaitu perolehan gelar dan ijazah, karena sebagian besar pesantren tidak mengeluarkan ijazah, sedangkan santri dengan ketulusan hatinya masuk pesantren tanpa adanya ijazah tersebut. Hal itu karena tujuan utama mereka hanya ingin mencari keridlaan Allah SWT semata, (4) sistem pesantren mengutamakan kesederhanaan, idealisme persaudaraan, persamaan, percaya diri

6 Ibid.

7 Abdurrahman Wahid, Menggerakan Tradisi: Esei-esei Pesantren, (Yogyakarta: LKiS, 2001), hal. 21. dan keberanian hidup. Alumni pondok pesantren tidak ingin menduduki jabatan pemerintah, sehingga mereka hampir tidak dapat dikuasai oleh pemerintah. ${ }^{8}$

Keunikan pesantren itu memang tidak hanya dalam pendekatan pembelajarannya, tetapi juga unik dalam pandangan hidup (world view) dan tata nilai yang dianut. Begitu pula sebuah lembaga pendidikan dapat disebut sebagai pondok pesantren apabila didalamnya terdapat sedikitnya lima unsur, yaitu: (1) kiai (2) santri (3) pengajian (4) asrama; dan (5) masjid dengan segala aktifitas pendidikan keagamaan dan kemasyarakatan. ${ }^{9}$

Demikian juga pondok pesantren memiliki tata hubungan yang khas dalam kependidikan dan kemasyarakatan, yaitu: (1) hubungan yang dekat antara kiai dan santri (2) ketaatan santri yang tinggi kepada kiai (3) hidup hemat dan sederhana (4) tingginya semangat kemandirian para santri (5) berkembangnya suasana persaudaraan dan tolong menolong (6) kuatnya semangat mencapai cita-cita (7) tertanamnya sikap disiplin dan istiqomah. ${ }^{10}$

\section{METODE}

Penelitian dilakukan dengan menggunakan metode kualitatif yang bertujuan untuk memahami konteks alami dan memahami subjek penelitian secara mendalam dan bersifat interpretatif, artinya mencari temukan fakta (Putra, 1994:67). Metode pendekatan penelitian yang digunakan adalah metode kualitatif naturalistik. Metode ini dipilih karena peneliti ingin melihat langsung berbagai kenyataan dilapangan yang dilakukan subjek penelitian tanpa menambah atau merubah peristiwa yang

8 Hasbullah, Sejarah Pendidikan Islam di Indonesia, (Jakarta: RajaGrafindo Persada, 2001), hal. 141.

9 Departemen Agama RI, Pondok Pesantren dan Madrasah Diniyah: Pertumbuhan dan Perkembangannya, (Jakarta: Direktur Jenderal 10 Kelembagaan Agama Islam, 2003), hal. 28.

Ibid. H.29 
terjadi dilapangan atau berusaha memahami perilaku subjek penelitian dari segi kerangka berpikir maupun bertindak dari subjek penelitian itu sendiri (Moleong, 2010:31).

Teknik pengumpulan data yang digunakan adalah wawancara, observasi, FGD, dan analisis dokumentasi. Analisis data pada penelitian ini menggunakan model Miles \& Huberman (Putra, 1994:67). Menurut Miles dan Huberman ada 4 (empat) macam kegiatan dalam analisis data kualitatif, yaitu pengumpulan data, reduksi data, model data dan penarikan/verifikasi kesimpulan, yang dapat digambarkan dengan model interaktif sebagai berikut (Miles, 1984:20):

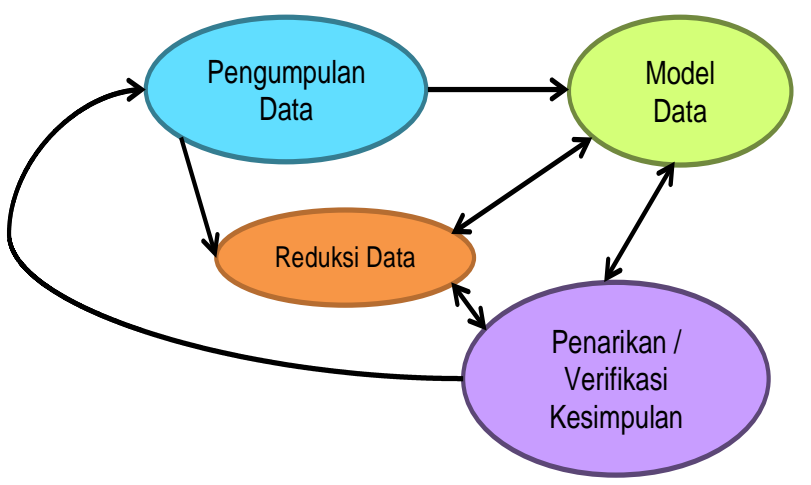

\section{Gambar 1. Model Analisis Miles \& Huberman}

Untuk memperoleh keabsahan data, peneliti menggunakan 4 (empat) teknik pemeriksaan keabsahan data, yaitu: perpanjangan keikutsertaan, triangulasi, pemeriksaan sejawat melalui diskusi, dan auditing.

\section{HASIL DAN PEMBAHASAN}

Berdasarkan hasil observasi \& wawancara dengan subyek informan, diperoleh data model pembelajaran karakter anak usia dini yaitu dengan cara (1) pembiasaan oleh guru \& (2) imitasi dari santri di lingkungan sekolah.

\section{Pembiasaan Perilaku oleh Guru RA}

Seperti halnya pembiasaan perilaku untuk anak usia dini yang biasa dilakukan oleh guruguru PAUD pada umumnya untuk habit dan perilaku rutinitas sehari-hari, anak-anak di RA
Al Hikam mempunyai panutan dan role model dari guru-guru di lingkungan RA dan lingkungan pesantren. Pembiasaan yang dilakukan oleh guru didominasi oleh pembiasaan spiritual dan pembiasaan sosial emosional dengan pusat kegiatan di masjid dan lokasi lain di sekitar pesantren pada umumnya. Pembiasaan sosial emosional yang dilaksanakan oleh guru kepada murid RA dilaksanakan dengan tujuan pembentukan karakter sosial dan solidaritas antar santri yang dibentuk sejak dini. Kebiasaan spiritual dilaksanakan oleh murid dimaksudkan guru-guru dan pengasuh ponpes untuk pebiasaan aktifitas-aktifitas rutin murid. Substansi spiritualitas yang ada di pembiasaan aktifitas spiritual, belum dimaksudkan untuk disampaikan kepada murid dengan pertimbanganpertimbangan kematangan kognitif \& sosial emosional yang belum terbentuk dengan sempurna.

Pembiasaan dilakukan disekitar masjid dilakukan dengan tujuan untuk membiasa-kan murid-murid RA, untuk selalu melaksanakan aktifitasnya dimulai dan berpusat pada masjid. Hal ini bertujuan untuk murid-murid RA memiliki kebiasaan menjadi santri sejak dini sesuai aktifitas yang biasa dilakukan oleh santri di sekitaran masjid. Pembiasaan yang dilakukan di sekitar masjid dimaksudkan oleh guru-guru RA \& pengasuh ponpes untuk membentuk keterikatan dan kelekatan aktifitas murid di masjid.

Substansi kebiasaan dan pembiasaan yang dilakukan guru-guru kepada murid-murid RA dilakukan sesuai dengan arahan dan himbauan dari kiai pengasuh. Kebiasaan-kebiasaan tersebut dimaksudkan untuk membentuk karakter santri sejak dini di lingkungan, khususnya pondok pesantren tersebut. Kiai pengasuh menyeleksi, membina dan mengarahkan tujuan perilaku dan pembiasaan dari guru kepada murid-murid RA, sesuai dengan visi misi pembangunan pondok 
pesantren yang ada. Visi misi pondok pesantren Al Hikam berkaitan erat dengan pembangunan manusia berpengetahuan modern, sesuai dengan peruntukan Pondok Pesantren dengan santri dari mahasiswa. Pembiasaan perilaku di lingkungan RA Al Hikam didasarkan pada perilaku scientific santri sejak dini.

Model pembiasaan perilaku yang berdasarkan scientific tersebut dikembangkan oleh subyek-subyek guru RA sesuai dari arahan kiai pengasuh pondok pesantren. Bentuk kurikulum secara nasional yang diterapkan di lingkungan RA Al Hikam tidak berbeda dengan kurikulum pendidikan anak usia dini pada umumnya yaitu Kurikulum Kurikulum 2013 Pendidikan Anak Usia Dini (K13 PAUD) yang berbasis scientific. Tidak terdapat problematika atau permasalahan tentang penerapan dan penyesuaian model pembiasaan perilaku dari lingkungan pondok pesantren dengan K13 PAUD, karena mempunyai basic scientific yang sama. Pengasuh pondok pesantren awalnya mempelajari substansi K13 PAUD untuk kemudian dianalisis dan diterapkan sesuai dengan hasil analisis dan kajian yang sudah dilakukan dengan berbagai penyesuaian. Namun tujuan K13 PAUD, tidak terdapat perbedaan atau pertentangan secara signifikan mengenai pembiasaan perilaku yang sudah dilakukan oleh subyek guru dan subyek lain di pondok pesantren dengan pembiasaan perilaku sesuai program K13 PAUD. Pembiasaan perilaku dengan basis scientific oleh RA bertujuan untuk membentuk karakter santri yang mampu mengembangkan ilmu pengetahuan dengan baik dan benar.

Pembiasaan perilaku dilaksanakan tidak hanya pada saat jam pelajaran saja, namun pembiasaan diprogramkan oleh subyek guru kepada murid untuk habit atau perilaku murid sehari-hari. Substansi perilaku yang diberikan semuanya, baik untuk orangtua maupun untuk guru di RA, dibina dan diarahkan oleh pengasuh ponpes secara rigid dan terstruktur, terutama untuk pembiasaan sosial emosional dan spiritual. Sebagian besar pembiasaan perilaku di rumah oleh orangtua tidak membutuhkan pengerahan kembali, dengan pertimbangan persamaan persepsi dan pandangan antara orangtua murid dan pondok pesantren. Sedangkan orangtua yang belum memahami pondok pesantren secara komprehensif, akan diberikan pengarahan secara mendalam oleh kiai pengasuh pondok pesantren. Aturan dan lingkungan yang dibentuk secara rigid, menghasilkan output karakter anak usia dini yang unik dan berbeda dengan anak usia dini lainnya.

\section{Imitasi dari santri pesantren di lingkungan sekolah RA}

Pembentukan karakter murid RA selanjutnya melaui metode imitasi dari santri pondok pesantren di lingkungan sekolah $\mathrm{RA} \mathrm{Al}$ Hikam. Murid-murid melihat dan mengalami secara langsung kehidupan santri di sekitar lingkungan RA. Semua perilaku dari santri yang teramati, mulai dari performance, social culture, sosial emosional, dan terutama perilaku spiritual yang ditunjukkan dan terbiasa dilihat oleh murid. Interaksi yang terjadi antara murid dan santri sangat sering terjadi, terutama saat aktifitas pengasuhan, pengawasan, dan komunikasi yang dilaksanakan oleh santri dengan murid. Dengan terjalinnya komunikasi dan interaksi yang kontinyu dan berlangsung setiap hari, maka bahasa dan pola komunikasi juga terbentuk berdasarkan interaksi yang terjadi. Guru-guru RA tidak jarang dibantu dalam proses pembelajaran di lingkungan RA oleh para santri yang ada. baik di lingkungan pembelajaran di dalam kelas maupun di dalam kelas melalui persetujuan dan prosedur tersendiri. Santri seringkali memberikan pembelajaran yang terkesan lebih menarik dibandingkan aktifitas rutin yang sudah dilaksanakan murid-murid RA. Karakter untuk 
model pembelajaran yang diharapkan terbentuk kepada murid adalah karakter santri pembelajar sesuai dengan karakter pondok pesantren yang cenderung scientific atau berilmu pengetahuan.

Interaksi yang terjadi antara santri dan murid RA mampu membentuk pola norma perilaku dan kepribadian yang sangat kuat pada aspek sosial emosional. Perilaku solidaritas juga menjadi nilai tambah tersendiri dari murid RA yang mampu berinteraksi dengan baik dengan para santri di lingkungan pondok pesantren. Role model pengasuhan juga bisa didapat dari perilaku santri kepada murid-murid RA yang mempunyai kecenderungan mengasuh yang lebih muda. Tidak jarang pengasuhan tersebut membentuk kelekatan antara santri dan muridmurid RA. Interaksi yang terjadi antara santri dan murid-murid RA membentuk karakter sosial emosional yang kuat antar santri dan murid. Karakter yang kuat tersebut muncul karena kerukunan antar santri yang terjalin di lingkungan pesantren.

Bentuk perilaku lain dari hasil interaksi murid dan santri adalah kehidupan kemandirian di dalam lingkungan pesantren yang kuat. Kemandirian yang dilakukan oleh santri dinilai sebagai perilaku yang wajib mampu dilakukan oleh murid-murid RA dengan porsi dan taraf perlakuan dengan tingkat yang berjenjang sesuai kronologis usia murid. Kemandirian perilaku santri yang diamati oleh murid-murid, hampir semuanya dapat dikerjakan oleh murid RA, seperti kebersihan diri, kerapihan performance, tatanan sewaktu masuk masjid, dan perilaku di dalam masjid. Kehidupan kemandirian santri di dalam pondok pesantren diamati secara langsung oleh kiai pengasuh dan diatur sedemikian rupa untuk tetap mandiri dan tertib. Karakter kemandirian adalah salah satu karakter kuat santri yang menjadi salah satu tujuan kiai pengasuh untuk membentuknya sejak usia dini. Dengan proses yang berlangsung setiap hari dengan kuantitas yang rutin, maka karakter santri melalui pembentukan \& pembiasaan perilaku santri kepada murid-murid RA akan terbentuk dengan baik.

Adapun untuk linkage pembelajaran karakter murid RA adalah sebagai berikut:

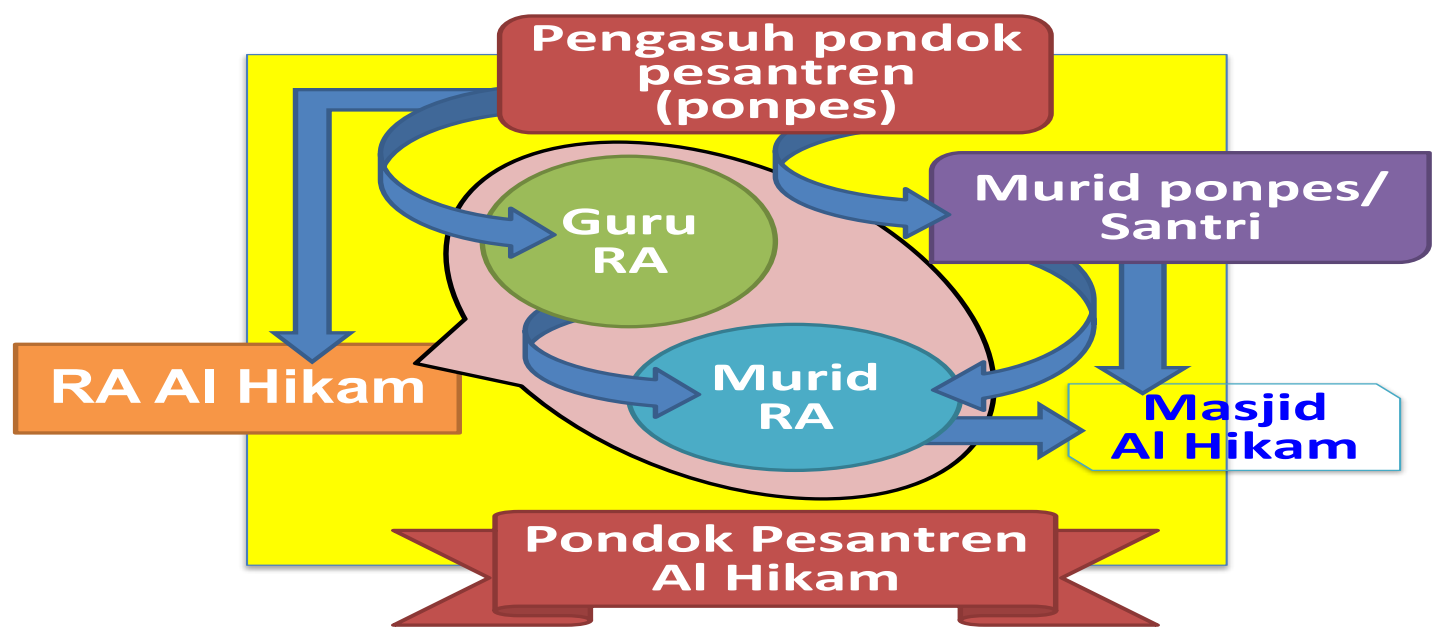

Gambar 2. Linkage Pembelajaran Karakter RA AL Hikam

Sedangkan berdasarkan hasil observasi \& wawancara dengan subyek informan, diperoleh data faktor-faktor yang mempengaruhi model pendidikan dan pembelajaran karakter anak usia 
dini di lingkungan ponpes adalah: (1) karakter pondok pesantren, (2) integritas dan komitmen orangtua, (3) keteladanan guru-guru RA.

\section{Karakter pondok pesantren}

Pondok pesantren Al Hikam dengan banyak santri dari mahasiswa memiliki salah satu karakteristik dimana para santri dididik untuk memiliki ilmu pengetahuan yang kuat. Karakteristik pondok pesantren tersebut tidak berbeda dengan tujuan pembentukan perilaku untuk membentuk karakter murid-murid RA dengan basis scientific. Karakter pondok pesantren yang kuat berasal dari pertimbangan dan keputusan kiai pengasuh saat mendirikan pondok pesantren. Tidak terdapat nota keberatan atau ketidak setujuan antara karakter pondok pesantren dengan model pembiasaan perilaku untuk membentuk karakter murid RA dari guru atau dari orang murid yang bersangkutan. Pertimbangan-pertimbangan lain dari guru dan orangtua untuk tidak keberatan dengan persamaan visi RA dan pondok pesantren adalah persamaan pada persetujuan dan intervensi perilaku yang telah ada. Segala pengambilan keputusan dan persetujuan model pendidikan dan pembelajaran yang ada di lingkungan pondok pesantren ada di kewenangan dari kiai pengasuh yang telah dipertimbangkan dengan baik sebelumnya.

Adapun untuk forum guru atau diskusi yang melibatkan guru atau orangtua murid terkait model pembelajaran karakter, adalah forum untuk memberi masukan dan pertimbanganpertimbangan dari segi psikologi, pendidikan anak usai dini, kesehatan dan model pembelajaran, dan kemudian akan dipertimbangkan dengan matang oleh kiai pengasuh pondok pesantren. Masukan dan pertimbangan yang ada akan selalu diolah dengan baik dan akan dikonfirmasi kepada pengusul oleh kiai pengasuh. Usulan pembelajaran karakter yang masuk di lingkungan RA tidak banyak terjadi, dan selama
RA berdiri, usulan tersebut bersifat aktifitas atau masukan dan bukan sebuah sanggahan. Subyek guru seringkali memberikan pertimbangan, opini, dan diskusi dengan pengasuh pondok pesantren dalam rangka peningkatan kualitas pembelajaran.

Pembelajaran karakter yang ada di lingkungan pondok pesantren bukan tidak diterima secara komprehensif, namun akan diolah \& disesuaikan dengan potensi pendukung yang terdapat di dalam pondok pesantren. Apabila ada aspek pembelajaran yang tidak sesuai, maka pengasuh pondok pesantren akan memberikan penjelasan jenis pertentangannya dan kemudian akan menggantikan atau menyesuaikan jenis pembelajaran yang lain.

Dalam kesempatan lain, pondok pesantren yang berbeda dan terdapat institusi pendidikan anak usia dini di dalamnya yang berbentuk kelompok bermain (KB), karakter edukasi dan proses pembelajaran yang membentuk karakter murid KB adalah untuk membentuk kreatifitas murid. Dengan segala keterbatasan yang ada, KB dalam pondok pesantren tersebut berusaha menumbuhkan kreatifitas yang tinggi melalui berbagai hasil karya murid. Demikian halnya dengan santri yang belajar di pondok pesantren tersebut, yang dituntut untuk menghasilkan karya tertentu. Subyek guru dan kiai pengasuh akan terus memberikan model pembelajaran yang menitikberatkan pada kreatifitas yang dihasilkan (product) dari masing-masing santri dan murid KB.

Dengan jenis, visi, tujuan atau karakter pondok pesantren yang berbeda, maka karakter yang berusaha dibentuk untuk masing-masing murid, khususnya anak usia dini akan berbeda pula pada aspek-aspek tertentu.

\section{Integritas dan komitmen orangtua murid}

Keteladanan orangtua murid dalam membentuk karakter murid di RA sangat dituntut oleh kiai pengasuh. Pondok pesantren berusaha memotivasi orangtua murid melalui 
integritas dan komitmen pendidikan anak yang tinggi hingga menjadi santri yang mempunyai komitmen untuk pembelajaran. Orangtua murid sangat antusias saat tahun ajaran baru dimulai, dan mereka sangat aktif untuk interaksi dan komunikasi dengan pondok pesantren atau dengan RA. Namun, subyek guru menilai komitmen yang dibangunnya akan menurun saat pertengahan tahun ajaran baru. Hal tersebut dikarenakan seiring dengan aktifitas yang semakin padat baik untuk orangtua maupun untuk murid-murid di RA. Adapun untuk komitmen dan integritas orangtua murid yang tetap tinggi, dikarenakan oleh pemahaman yang sama, lulusan santri pondok pesantren, dan pengetahuan yang cukup pada pendidikan anak usia dini. Untuk rendahnya komitmen dan integritas orangtua murid kepada murid RA banyak disebabkan karena alasan kesibukan, ekonomi, dan kurangnya pengetahuan tentang anak usai dini secara komprehensif.

Keteladanan orangtua murid untuk membentuk karakter murid juga dituntut untuk mempunyai jenis perlakuan yang sama antara yang ditunjukkan oleh guru di lingkungan sekolah. Model pembelajaran dan pendidikan khususnya untuk pembiasaan perilaku untuk membentuk karakter murid yang tidak diteruskan di rumah, sangat berisiko untuk gagal dan berakibat ketidakharmonisan perilaku di rumah dan sekolah. Kegagalan orangtua meneladani bentuk sikap yang diharapkan oleh pengasuh pondok pesantren mempunyai potensi kegagalan dalam membentuk karakter murid yang diharapkan menjadi santri. Pembatasan murid dalam bergaul oleh orangtua, tidak diberikan kesempatan untuk aktif di masjid, spoiling, adalah penyebab kegagalan model pembelajaran karakter murid usia dini.

Subyek guru memandang orangtua mempunyai akses informasi untuk anak yang hampir tidak terbatas. Dengan era informasi yang accessible, maka orangtua juga mempunyai pandangan tertentu untuk model pendidikan anak usia dini, meskipun seringkali pemahaman itu tidak berguna atau malah bertentangan dengan pondok pesantren. Orangua murid seringkali langsung percaya dengan model pembelajaran baru yang baru diperolehnya melalui media sosial. Ada beberapa orangtua yang mengkomparasikan karakter murid satu dengan sekolah lain, dan sebagian besar mereka mulai berusaha untuk menyesuaikan pendapat dengan pondok pesantren. Namun sebagian besar mereka gagal untuk menyesuaikan pendangan pengembangan karakter murid karena pandangan \& pengetahuan dasar yang mereka miliki tidak konstruktif dan mendasar.

\section{Keteladanan guru-guru RA}

Keteladanan guru-guru adalah kunci utama dalam pengembangan karakter murid di RA Al Hikam, seperti halnya pengembangan karakter di lingkungan PAUD secara uum. Guru-guru yang ada dipilih dan diseleksi secara langsung oleh kiai pengasuh ponpes dengan mekanisme tersendiri yang disesuaikan dengan karakter santri ponpes dan kiai pengasuh sendiri. Tujuan seleksi adalah menjaring karakter santri pada guru-guru terbaik untuk mendidik karakter murid RA AL Hikam.

Keteladanan guru kepada murid mutlak diperlukan RA Al Hikam dengan pertimbangan subyek guru adalah subyek utama untuk memberi pembelajaran \& pendidikan karakter kepada murid yang wajib dimulai dari diri sendiri. Aktifitas dan interaksi subyek guru dimonitor dan dievaluasi oleh kiai pengasuh melalui mekanisme tersendiri secara ketat dan mengikat. Monitoring evaluasi dilaksanakan oleh kiai pengasuh melalui diskusi dan observasi secara periodik dengan tujuan review pembelajaran yang sudah diberikan, termasuk didalamnya pembelajaran karakter kepada murid. Dengan karakter santri yang ada pada guru, kiai pengasuh bermaksud untuk memberi 
keteladanan dengan cara langsung maupun tak langsung, misalnya perilaku dan sikap guru, model pendidikan, dan pembelajaran yang mampu diadopsi dengan baik oleh murid.

\section{KESIMPULAN DAN SARAN}

Berdasarkan penelitian yang dilakukan, model pembelajaran karakter anak usia dini di RA Al Hikam yaitu dengan cara (1) pembiasaan oleh guru \& (2) imitasi dari santri di lingkungan sekolah. Sedangkan faktor-faktor yang mempengaruhi model pendidikan dan pembelajaran karakter anak usia dini di lingkungan ponpes Al Hikam adalah: (1) karakter pondok pesantren, (2) integritas dan komitmen orangtua murid, (3) keteladanan guruguru RA.

Karakter pondok pesantren yang unik dengan kiai pengasuh sebagai sentral figur di lembaga pendidikan, lokasi yang terintegrasi antara lingkungan pendidikan, masyarakat atau sosial, dan spiritual dalam beribadah, menghasilkan karakter individu yang mempunyai ciri khas tersendiri dan unik. Pembelajaran sosial emosional melalui interaksi yang kuat antara murid dengan santri, mampu membentuk karakter solidaritas yang tinggi dan jiwa sosial yang lebih tinggi yang dihasilkan melalui proses pembelajaran yang dialami oleh murid RA Al Hikam setiap hari.

Model pembelajaran karakter di RA Al Hikam di lingkungan ponpes Al Hikam bertujuan membentuk karakter santri pada murid RA Al Hikam sejak dini, dengan ciri khas sebagai santri yang mempunyai pengetahuan yang kuat dengan aktifitas yang berpusat pada masjid, sebagaimana karakter yang dibentuk oleh ponpes Al Hikam kepada santri mahasiswa Al Hikam, melalui keteladanan guru dan santri yang diawasi dengan ketat oleh kiai pengasuh. Pembelajaran karakter di lingkungan RA Al Hikam tidak terbatas hanya saat berada di lingkungan RA Al Hikam, namun wajib dilanjutkan oleh orangtua murid di lingkungan keluarga dengan tujuan keberlanjutan dari pembelajaran karakter murid RA Al Hikam untuk memperoleh karakter yang terbaik manusia.

\section{DAFTAR PUSTAKA}

Abdurrahman Wahid, Menggerakan Tradisi: Esei-esei Pesantren, Yogyakarta: LKiS, 2001

Departemen Agama RI, Pondok Pesantren dan Madrasah Diniyah: Pertum-buhan dan Perkembangannya, (Jakarta: Direktur Jenderal Kelembagaan Agama Islam, 2003 Hasbullah, Sejarah Pendidikan Islam di Indonesia, (Jakarta: RajaGrafindo Persada, 2001)

Lydia Freyani Hawadi, Pedoman Pendidikan Karakter Pada Pendidikan Anak Usia Dini, Direktorat Pembinaan Pendidikan Anak Usia Dini, Kementerian Pendidikan Nasiona, 2012

Sigit Dwi Laksana, Urgensi Pendidikan Karakter, MUADDIB, Vol.05 No.01 Januari-Juni 2015, jurnal.umpo.ac.id, diakses: 01/08/2016

Sofyan Sauri, Peran Pesantren Dalam Pendidikan Karakter, MAN Baturaja: siap-sekolah.com - page:3, diakses: 01/08/2016 